DOI: $10.2478 /$ pof-2018-0039

VOLUME 10, ISSUE 3, 2018

ISSN: 2036-5438

\title{
Article 7 TEU: From a Dormant Provision to an Active Enforcement Tool?
}

by

Martina Coli*

Perspectives on Federalism, Vol. 10, issue 3, 2018 


\begin{abstract}
For a long time considered, improperly, a sort of 'nuclear' option, Article 7 TEU is the key EU Treaty provision in the field of values enforcement. In the context of the Union's current rule of law crisis, such a provision deserves the greatest attention, especially after the European Commission's proposal in December 2017 to trigger the procedure against Poland, under Article 7(1) TEU. This article contributes to understandings of the provision by reviewing its main features and contextualising its deployment in the general Polish rule of law crisis, with the aim of evaluating whether it can now be considered as an operational instrument for values enforcement. Although the Commission's (late) decision to activate the Article 7(1) TEU procedure should be welcomed as a major effort in restoring the rule of law within the European Union, the (perceived and real) limits of Article 7 TEU and the inertia of the EU institutions cast a shadow over the procedure's effective implementation.
\end{abstract}

\title{
Key-words
}

Article 7 TEU, European Union, rule of law, Poland, enforcement of values 


\section{Introduction}

The European Commission's 20 December 2017 proposal to trigger the procedure envisaged by Article 7(1) TEU against Poland may have come as a surprise for those who were not following the case closely. Nevertheless, such an event was the culmination of two years of dialogue between the Commission and Poland, through which the EU tried to act in response to the recent and rapid ongoing erosion of the rule of law in that country. The degradation of Poland's liberal structure is one of the greatest signs of the Union's rule of law crisis, that is, an ongoing process in some Member States of widespread and increasing denial of the founding values of the European Union, amongst which is the rule of law.

The rule of law is a concept at the very heart of the European legal order, enshrined in Article 2 TEU, the 'homogeneity clause', which encapsulates the axiological foundation of the European Union, enlisting those values that are 'common to the Member States' and on which the EU is founded. Despite its ambiguity, the core of this principle encompasses six key elements reiterated by the Venice Commission, namely: legality, legal certainty, probibition of arbitrariness, access to justice, respect for buman rights; non-discrimination and equality before the law. ${ }^{\mathrm{I}}$ This work is therefore based on the idea that the rule of law can be viewed as a constitutional principle of the EU and a cornerstone among the other EU founding values. Accordingly, a substantive notion of the rule of law will be embraced throughout this work, denoting a system where not only laws are applied and enforced thoroughly, but also democracy and the enjoyment of fundamental rights are guaranteed.

As the outcomes of talks with the Polish government were disappointing, to say the least, the Commission then decided to initiate, for the very first time, the preventive mechanism foreseen by Article 7 TEU. Such a provision is specifically envisaged by the Treaties to prevent or sanction the most serious breaches of the EU founding values, now solemnly entrenched in Article 2 TEU. The Commission's action is a unique case in the Union's history, as Article 7 TEU has been widely acknowledged, by both politicians and scholars, as a sort of nuclear and practically unfeasible option; a definition which relates 
mostly, albeit not exclusively, to its political nature and the expected consequences of its use.

Against this background, this work will assess whether the 'nuclear bias' against Article 7 TEU has finally been removed, making it an operational instrument for values enforcement. In doing so, this article firstly revisits the most important features of the mechanisms envisaged by Article 7 TEU (1), with the aim of explaining why for a long time it has been (improperly) considered a sort of 'nuclear' provision (2). Then, the focus will shift towards the Commission's proposal to initiate the procedure envisaged by Article 7(1) TEU. The issue will be firstly contextualised by briefly recalling the most recent (worrisome) developments in Poland as well as the measures taken by the European Commission to address these (3). Finally, the Commission's decision to trigger the Article 7(1) procedure will be analysed, in order to evaluate the suitability of the measure and whether this development may be considered as a major change in the attitude towards the procedures under Article 7 TUE (4). In conclusion, some considerations on the recent Commission's initiative will be made. The point this work would like to make is that unfortunately, due to the (perceived and real) limits of Article 7 TEU and the inertia of the EU institutions, the rule of law is still hardly enforceable in the European Union. ${ }^{\text {II }}$

\section{What is Article 7 TEU about? Origin and content of the provision}

Although it is a broad and ambiguous legal concept, the rule of law has been widely acknowledged as one of the major principles on which European constitutional systems should be founded. ${ }^{\text {III }}$ It is not only one of the backbones of the European Union but also of all the constitutional systems of the Member States, now fully part of the European values entrenched in Article 2 TEU:

The Union is founded on the values of respect for human dignity, freedom, democracy, equality, the rule of law and respect for human rights, including the rights of persons belonging to minorities. These values are common to the Member States in a society in which pluralism, non-discrimination, tolerance, justice, solidarity and equality between women and men prevail. 
Although the respect for EU founding values in general, and the rule of law in particular, is vital for the survival of the European supranational legal order, at the time the European Economic Community (EEC) was founded no mechanisms to address and sanction violations of EU values were included in the Rome Treaty. On the one hand, in light of the fact that the Community's primary role was related with market integration, issues such as the respect for democracy, human rights and rule of law were not considered of paramount relevance. On the other hand, the role of the European Court of Human Rights as regards monitoring compliance with such values led to a sort of implicit division of roles with the European Union (De Búrca 2004: 684).

The situation only evolved with the Amsterdam Treaty of 1997, where a first mechanism to sanction breaches of EU values was included. The main driver for the establishment of this sanctioning system was the perspective of the big Eastern enlargement, as existing Member States were concerned about the incapacity of new candidate countries to reach their thresholds as regards legal approaches, human rights and the rule of law (Sadurski 2010: 6). Indeed, the first of the 'Copenhagen criteria' which, developed in 1993, laid down the essential conditions to be fulfilled to become a member state of the EU, refers to 'stability of institutions guaranteeing democracy, the rule of law, human rights and respect for and protection of minorities' ${ }^{\text {IV }}$ an expression very much in line with what is now stated in Article 2 TEU.

The precursor to the sanctioning procedure under Article 7 foresaw a mechanism to determine 'the existence of a serious and persistent breach by a Member State' of the European founding values, as well as to apply sanctions. ${ }^{\text {VI }}$ Indeed, after such a determination, made through a unanimity vote of the European Council, the Council could decide by qualified majority to suspend certain rights of the Member State concerned.

As regards the preventive mechanism of Article 7, it was added only some years later, with the amendments introduced by the Treaty of Nice in 2001. The catalyst for such a development was the Haider affair in Austria which followed the great electoral support received in the 1999 Parliament election by the far-right populist Freedom Party (FPÖ) led by the governor of the federal Land of Carinthia Jörg Haider. After months of negotiations, the FPÖ took part in the coalition government led by Wolfgang Schüssel, the leader of the centre-right People's Party (ÖVP). Although Haider himself decided not to 
participate, the event was the source of much concern across Europe, as Haider and other FPÖ members were well-known for their xenophobic and racist positions.

In the following months, the other Member States tried to organise a concerted response, supported by the Portuguese Council presidency (Black and Connolly, 2000). On 31 January 2000, the Governments of 14 Member States issued a statement in which they declared that they were not willing to accept 'any bilateral official at political level with an Austrian Government integrating the FPÖ'. Moreover, they denied support to any Austrian candidates seeking positions in international organisations and they also decided that 'Austrian Ambassadors in EU capitals will only be received at a technical level'.

While the EU Treaties offered a specific sanctioning provision for addressing the issue, Article 7, Member States decided not to use such a mechanism, the employment of which was urged only by the European Parliament. ${ }^{\text {VIII }}$ As such, they decided to rely on diplomatic and bilateral sanctions, which, although concerted and agreed among all Member States, quickly showed their limitations. Indeed, contacts between the Austrian government and other Member States were maintained in the context of European institutions (Sadurski 2010: 14). ${ }^{\mathrm{IX}}$ Moreover, after the report on the commitment of the Austrian government to respect the common European values commissioned from a group of experts, the "wise men', ${ }^{\mathrm{x}}$ the French Presidency decided to lift the sanctions, which had also the unexpected and negative consequence of fuelling Eurosceptic and populist movements in Austria.

Even though Article 7 was not used in order to deal with the Haider Affair, this event represented a strong impetus for expanding the possibility of a Union's action in the field of values' safeguarding. In the report's conclusions, the authors recommended the introduction of a preventing and monitoring mechanism in Article 7, specifically aimed at dealing such situations within the EU framework, right from their outset (Ahtisaari, Frowein and Oreja 2001: par. 117-118). This recommendation was then followed during the drafting of the Nice Treaty and paved the way for the introduction of a preventing mechanism in Article 7, that is, the possibility of reacting to the clear risk of a serious violation of EU values. ${ }^{\mathrm{XI}}$ Following the proposal by one-third of the Member States, the EP or the Commission, the TEU now foresees a specific warning procedure to be activated by the Council, acting by a majority of fourth-fifth of its Members, after having obtained the consent of the European Parliament and having heard the Member State concerned. 
As a result, Article 7 TEU now consists of a double procedure: a preventive mechanism, described at paragraph 1, and a sanctioning one at paragraphs 2 and 3 . Although these may seem to be two steps of a single instrument, these two procedures should instead be understood as two different and autonomous mechanisms. Notably, they are different, because while the former requires the determination that there is a clear risk of a serious breach, the latter applies only in cases where a serious and persistent breach of the values is already in place. They are also autonomous, as the use of the preventive mechanism does not imply that the sanction mechanism should also be activated. At the same time, the sanction mechanism does not require the prior activation of the preventive mechanism. As Besselink pointed out, 'barking', the warning procedure, and 'biting', the sanctioning one, are 'two different ways to respond to a rule of law crisis' (Besselink 2017: 133).

With the entry into force of the Lisbon Treaty Article 7 underwent only minor changes. As regards the warning mechanism, with respect to the previous version, the Lisbon Treaty slightly changed the provision, entrusting broader monitoring powers to the Council, together with the possibility of issuing recommendations before the determination of the existence of a clear risk of serious breach of values is made (Besselink 2017: 133-134).

If changes in the situation occur, it is for the Council to determine the modification or the lifting of sanctions, acting by a qualified majority (paragraph 4).

Voting arrangements are laid down in Article 354 TFEU: these provide that, in the European Council and in the Council, representatives of the Member State concerned can neither take part in the vote, nor be counted in the calculation of the majorities. As regards to the voting requirements for the European Parliament, Article 354 requires 'the twothirds majority of the votes cast, representing the majority of its component Members'.

A key feature of Article 7 TEU is its scope of application, which is broader than the one of infringement procedures. Indeed, such a provision is considered horizontal and general in scope; the actions of the European Union in values enforcement, rather than being limited to areas covered by EU law, also apply to areas where the Member States act autonomously. The rationale of this feature is linked to the safeguard of the trust between the Member States, as clarified by the Commission, 'here would be something paradoxical 
about confining the Union's possibilities of action to the areas covered by Union law and asking it to ignore serious breaches in areas of national jurisdiction' XII

On the other hand, Article 7 not only has a broad scope of application but also is lex specialis since it does not exclude the application of Articles 258, 259 and 260 TFEU as mechanisms for values protection when the breach of the latter falls within the scope of EU law.

\section{A long story of non-application of Article 7 TEU}

As a matter of fact, the introduction of the Article 7 TEU procedures did not lead to reducing risks of values infringements within the European Union. Despite the magnitude and seriousness of earlier values infringements within the European Union, ${ }^{\text {XIII }}$ before the recent Polish case the mechanisms under Article 7 TEU had never been activated, either in sanctioning or in the preventing forms. Since its inclusion in EU Treaties, Article 7 TEU has been extensively seen as a sort of 'nuclear option', as the former Commission's President Barroso called it in 2012, ${ }^{\mathrm{XIV}}$ and its deployment was largely considered as a lastresort and practically unfeasible. The reasons behind this idea have been mostly related to four main drawbacks.

\subsection{A provision of political nature}

The element which has been considered as the main limitation of Article 7 TEU relates to the high thresholds required for its activation and the political discretion involved in its triggering. Reinforced qualified majority and unanimity are indeed the main voting requirements for the determination of the clear risk and the existence of values breaches, while the decisive role lies in the hands of the Council; in contrast, the role of the Commission is almost exclusively limited to a right to initiative. ${ }^{\mathrm{xV}}$

Thresholds are particularly high for the procedures set out in paragraphs 2 and 3, since the former requires unanimity in the European Council, while the latter needs a reinforced qualified majority and also a successful use of the procedure under Article 7(2). As far as Article 7(3) is specifically concerned, another limitation is that this provision is unclear in respect to what kind of sanctions can actually be imposed. ${ }^{\text {XVI }}$ This vagueness gives wide discretion to the Council, thus increasing the risk that political rather than legal 
considerations will drive the decision as regards the substance of sanctions. The situation is slightly different for the preventing mechanism, where the majority required is lower, namely the fourth-fifths of the Council's members, the Member State concerned does not vote and there is no express reference to sanctions.

Furthermore, according to Article 269 TFEU, the jurisdiction of the Court of Justice of the $\mathrm{EU}(\mathrm{CJEU})$ is limited to an oversight of the legality of an act adopted by the Council or by the European Council under Article 7 TEU 'solely at the request of the Member State concerned by a determination of the European Council or of the Council and in respect solely of the procedural stipulations contained in that Article'. Such a limitation of jurisdiction is an exception to the Court's general competence stated in Article 19 TEU. This fact clearly highlights the political nature of the Article 7 procedures, as well as the reluctance of the Member States to create an effective and supranational judicial control.

As a conclusion, it has been suggested that the nature of the Article 7 procedures involves such high 'considerations of political opportunity' that hardly any Member States would be willing to deploy this mechanism, preferring instead to be guided by 'a habit of mutual indulgence' (von Bogdandy et al 2012). For a long time, this view has contributed to the depiction of Article 7 as a politically unfeasible provision.

\subsection{Article 7 TEU v. the respect for national identity}

One of the most frequent justifications for the prevention of the use of Article 7 TEU is the claim for the non-interference of the EU institutions in area not covered by Union law, pursuant to the idea that a provision is not a viable option whenever its use might imperil the 'national identity' of the Member State concerned. Such a statement is usually supported with a reference to Article 4(2) TEU, the 'national identity' clause. ${ }^{\text {XVII }}$ This provision codifies the 'defensive concerns' championed by some national Constitutional Courts, supporting the idea of a relative nature of the primacy of EU law, rather than the absolute concept embraced by the CJEU (Guastaferro 2012: 4). Indeed, as the Court of Justice has affirmed many times, EU law is characterised by some very peculiar features such as autonomy, primacy and direct effect. ${ }^{\mathrm{XVIII}}$ These essential characteristics shape a 'structured network of principles, rules and mutually interdependent legal relations linking the EU and its Member States' ${ }^{\mathrm{XIX}}$ Such a legal structure is itself based on compliance, both 
by the Member States and EU Institutions, with the founding values enshrined in Article 2 TEU because the latter is essential for the uniform application of EU law. ${ }^{\mathrm{xx}}$

Since Article 4(2) TEU does not specify who is in charge of the definition, or determination, of the idea of national identity, such a determination may have some disruptive implications as regards the uniform application of Union law, which would be severely undermined if Member States were free to use national rules to justify derogation from EU law. The risk is therefore that any Member State may declare that it can freely decide what national identity means in its case and, according to this definition, set limits to the Union's action. It was not by chance that, right from the very beginning, the leader of the Hungarian Government Viktor Orbán has justified the country's deviation from EU values by referring to the safeguard of the Hungarian constitutional identity, as guaranteed in Article 4(2) TEU. The judgment of the Hungarian Constitutional Court of 5 December 2016 (Decision 22/2016. (XII. 5.) AB on the Interpretation of Article E) (2) of the Fundamental Law) is illustrative in this respect as the Court, loyal to the Fidesz government, developed an ultra vires review according to which recognising the primacy of EU law could not encroach on the sovereignty of Hungary and its constitutional identity (Halmai 2017: 152).

In a nutshell, can this respect for national identities prevent the EU institution from launching the Article 7 procedure or, even worse, might this clause legitimate derogation from the values entrenched in Article 2 TEU?

While this seems convincing, such an opinion is difficult to argue if we go through a careful interpretation of Article 4(2) TEU. Although this provision did not define the meaning of 'national identity', the core of the concept refers exclusively to those elements which are so enshrined in national constitutions to be considered inherent in their fundamental structures, political and constitutional' to the Member State. By contrast, values established in Article 2 TEU, are not only the very basis of the Union's identity but are also 'common to the Member States', affecting their identity, too (Pinelli 2012: 8). Threatening these values at the national level entails the risk of jeopardising the Union's architecture.

Article 4(2) TEU does not protect 'an entirely pre-political or pre-constitutional understanding of national identity' (von Bogdandy and Schill 2011: 1430). Demanding respect for national identity under Article 4(2) TEU cannot be conceived of as a derogation 
from compliance with the Union's fundamental values established in Article 2 TEU and, consequently, cannot be used by a Member State as a pretext to breach those values or to oppose sanctions adopted through Article 7 TEU.

\subsection{The risk of a popular backlash}

A perceived threat associated with the use of the procedures envisaged by Article 7 TEU relates to the side effects of a centralised enforcement of values. Indeed, one of the ideas behind opposition to the use of Article 7 was the fear of worsening national resistance to the Union (The Rule of Law in the Union, 2016: 602). On the one hand, a punitive approach may nurture bad feelings towards the EU among civil society, fuelling the campaigns of populist parties as well as criticisms of the rule of law and human rights (Enforcing the rule of law in the EU, 2016: 772). Since sanctions are never popular among those who are subject to them, the Union's actions may easily appear too intrusive into citizens' lives, especially in case of a country where popular dissatisfaction and frustration has allowed far-right or populist parties to win elections. ${ }^{\text {xxI }}$ In the worst case, sanctions may seriously compromise the democracy-building process, or provoke 'illiberal' Member States to challenge the EU's legitimacy, notably in cases where the values' crisis concerns fields falling within the Member States' own competence. Objections and popular resistance to EU sanctions, perceived as illegitimate and inequitable, may easily raise questions about the respect of the Union's competences and limits, challenging the legitimacy of the EU. The worst result of this trend may be that of undermining the authority of EU law and the EU construction and project. On the other hand, the use of sanctions runs the risk of damaging trust between the EU and its Member States, which is essential for cooperative relations between them and, in the end, also for the survival of the whole integration project (Bieber and Maiani 2014: 1091-1092).

The above reasoning is clearly rational; external interventions should thus be excluded whenever the national situation will realistically be 'self-correcting' (Muller 2011). Yet, this is not the case in serious rule of law violations such as those happening in Poland and Hungary, where the current governments have shown themselves to be fully aware and willing to pursue their constitutional and 'illiberal' revolutions. (Bugaric 2016: 97-98). 
Moreover, since, as often suggested by the European Commission and also affirmed throughout this work, the rule of law can be read in a substantive way as the cornerstone of EU values, the intervention of the EU should be welcomed in order to stop the deterioration of the rule of law and uphold European values.

This is not to say that Article 7 TEU should be triggered irresponsibly. Indeed, the provision itself acknowledges, as an explicit limiting factor to sanctions, that the Council shall 'take into account the possible consequences of such a suspension on the rights and obligations of natural and legal persons' (Article 7(3)). Hence, the consequences of sanctions on populations should be carefully considered and evaluated, encouraging their wise, selective and reasonable use.

\subsection{How to define a 'serious and persistent breach'?}

The last sensitive issue associated with Article 7 TEU relates to the criteria for its activation. It is well-known that implementation of Article 7 can only respond to very serious violations of EU values, but what are the actual thresholds for triggering this procedure? How can we establish whether these thresholds are met?

Unfortunately, defining the notion of 'serious and persistent breach' of the values referred to in Article 2 TEU is not an easy task. The European Commission and the European Parliament have tried to identify some indicators and possible criteria to set these thresholds, ${ }^{\text {XII }}$ which have been followed by other possible definitions from the academic side. As one might well imagine, individual, sporadic breaches of values are not enough to activate the Article 7 TEU procedures as, though deplorable, small and periodic rule of law infringements are difficulties faced by all democratic societies. Mechanisms which are highly political and of a high impact such as the ones foreseen by Article 7 are not meant to tackle these kinds of violations. Healthy democracies should have the legal mechanisms to address these issues through domestic procedures, and they may also resort to the ones foreseen at the European and international levels.

Since thresholds for activating Article 7 should be much higher than individual breaches of values, it has been widely acknowledged that what is needed to satisfy the seriousness criteria is the systemic nature of the violations (von Bogdandy and Ioannidis 2014: 74). This threshold can be met either if domestic institutions are not able to cope with the values, or in the case of a deliberate choice of violating them, as is the case of the 
reforms in Hungary and Poland. Yet, stressing the systemic feature of breaches further helps to explain why the procedures under Article 7 have largely been acknowledged as an unfeasible, last-resort and nuclear option.

Despite efforts made to clarify the topic, it is still difficult to clearly state which concrete violations correspond to the seriousness criteria of values' breaches. The models presented so far are too general and vague to be recognised as a real threshold, and unable to clearly identify a breach of EU values, or a clear risk of it. Without doubt, the activation of Article 7 procedures requires the existence of a threat of particular seriousness and duration. However, the actual notion of the seriousness criteria is still far from clear.

An approach that gives substance to the thresholds for activating Article 7 procedures is therefore probably needed in order to assess their actual operational potential.

\subsection{Article 7 TEU beyond the 'nuclear myth'}

As the analysis above has shown, the procedures envisaged by Article 7 TEU suffer from being of an extremely political and discretional nature. This circumstance is intensified by the lack of clear benchmarks aimed at giving substance to the criteria for the activation of the two mechanisms as well as the possible side-effects of the measure in terms of popular support.

For a long time these shortcomings made Article 7 a dormant, and nuclear, provision; however, notwithstanding these limitations the Article should instead be considered as what it actually is: an important legal instrument at the Union's disposal. The characterisation of Article 7 as a 'nuclear option' has been definitely overstated. A system that claims to be a 'Community of law', based on the rule of law, should have the foresight to include mechanisms to prevent and sanction non-compliance with its founding values. In this respect, Article 7 has the merit to 'enhance supranationalism' within the EU (Sadurski 2010: 33-34) notably by overcoming the issue of competence by addressing violations committed by any Member State regardless of whether or not they were carried out implementing Union law. It represents a key feature of the values-protection system within the EU, giving it (at least formal) credentials to define itself as 'a Community based on the rule of law, XxIII and to stress that violations of the founding values by any Member State concern not only that country but the European Union as a whole. 
In this respect, the recent decision of the European Commission to (finally) trigger the procedure in the Polish case should be definitely welcomed.

\section{Poland and abuses of the rule of law: an overview}

In May 2015 the Law and Justice Party (Prawo i Sprawiedliwośc, hereafter PiS), led by Jarosław Kaczyński, won the presidency of Poland with the election of President Andrzej Duda. A few months later, in October, PiS also won the Polish parliamentary elections. The path the country started to follow from that moment was anything but promising in terms of rule of law and respect for European values. In particular, the most worrisome measures concerned the reform of the judiciary; these risked undermining judicial independence as well as democratic checks and balances.

The main target of such illiberal reforms was the Polish Constitutional Tribunal. Since an overarching analysis of the overall context is beyond the ambition of this work, here it is enough to recall some of the key events that raised concerns over the rule of law situation in Poland and paved the way for the Commission's actions.

In order to respond to the worsening situation of the rule of law in Poland, on 1 June 2016 the European Commission decided to launch for the very first time the new mechanism foreseen by the EU Framework to strengthen the Rule of Law (hereafter New Framework) by issuing a rule of law opinion against the country (Pech 2016). Such a soft law instrument, set out by the Commission in 2014 to tackle rule of law backslidings, is conceived of as an additional mechanism and an upstream process to the launch of the procedure under Article 7(1) TEU: a sort of structural dialogue engaged between the Commission and the 'rogue' Member State, in order to prevent the emergence of systemic threat to the rule of law. ${ }^{\text {xxiv }}$ Indeed, the mechanism envisages a three-stage procedure at the end of which, in a case of an unsatisfactory outcome, the Commission may decide to evaluate the launch of the Article 7 TEU mechanisms. Before taking such as step, the Commission performs an assessment of the rule of law situation in the country concerned and, if it is of the opinion that a systemic rule of law threat is emerging, it will substantiate its concerns in a 'rule of law opinion' to be sent the Member State in order to start a dialogue. If no such cooperation follows, the Commission will then issue a 'rule of law 
recommendation' where it will set a deadline for compliance and recommend that the Member State find a solution to the problems identified, while also suggesting some specific instructions and indications.

Since the overall context of the rule of law deterioration in Poland is important in order to understand whether the actions of the Commission were justified and appropriate, the main contested measures took by the Polish government as well as the main critiques and concerns expressed by the Commission should now be retraced.

The Commission started paying attention to the situation of the Judiciary in Poland with regard to the dispute over the appointment of the members of the Constitutional Tribunal (hereafter Tribunal). In November 2015 the Sejm (Sejm Rzecaypospolitej Polskiej: the lower house of the Polish Parliament) amended the 'Law on the Constitutional Tribunal' in order to make the annulment of previous judicial appointments possible. Consequently, the Parliament dismissed five judges appointed by the previous legislature and nominated five new members. On 9 December the Tribunal issued a judgment in which it invalidated the appointment of three of the judges elected by the new Sejm since it was not entitled to elect them. ${ }^{\mathrm{xxv}}$

On 22 December, the Sejm amended the Law on the Constitutional Tribunal and disposed that the adjudication on the general composition of the Tribunal, the full bench, should have required the attendance of at least 13 out of 15 of the Tribunal's judges. Moreover, it introduced new voting requirements for passing a decision in the full bench, a two-thirds majority, while the dates of its hearings had to be established as regards the chronological order of the cases. According to the Commission, the combined effect of these new measures 'undermined the effectiveness of the Constitutional Tribunal as a guarantor of the Constitution', ${ }^{X \mathrm{XVI}}$ while for the Venice Commission it 'would seriously hamper the effectiveness of the Constitutional Tribunal'XxvII

In some respects, the 'Law on the Constitutional Tribunal' of 22 July 2016 slightly improved the situation. The attendance quorum was lowered to 11 judges, while a simple majority of votes replaced the two-thirds stipulation. The chronological order rule of case hearings (sequence rule) was tempered by allowing the President of the Tribunal to diregard it in some very specific cases and if this is justified by the necessity to safeguard the rights or freedoms of citizens, national security or the constitutional order'. ${ }^{\text {XxvIII }}$ Yet, 
other measures introduced by the Law raised further concerns as they risked preventing the effective work of the Tribunal. As noticed by the Venice Commission, the amendments to the sequence rule still did not guarantee sufficient flexibility in the work of the Tribunal, as they granted the power to apply the limited exception to the President. ${ }^{\text {xxIx }}$ Moreover, the powers of the Prosecutor General, who from March 2016 also became the Minister of Justice, were dramatically increased. Since his presence is always required in cases before the full bench, including complex ones, his absence is now sufficient to prevent hearings to take place. ${ }^{\mathrm{xx}}$ Taking into account the joint effect of these reforms, it was not hard to imagine a risk of politicisation of the Tribunal. Such a concern was also reinforced by the fact that the request of three judges was sufficient to refer a case to the full bench (Article $26(1)(1)(g))$.

The Tribunal itself struck down the law-package twice. Firstly, in March 2016 it declared unconstitutional many of the provisions of the law of November 2015 and stated that three out of the fifteen judges composing the full bench were not constitutionally appointed. ${ }^{\text {XXI }}$ Then, in August the Tribunal rejected the newly problematic measures introduced by the Law of July 2016 and mentioned above, while restating the unresolved issues of its previous judgment (Koncewicz 2016a). Yet, none of these rulings was made public.

All these concerns were addressed in the Commission's action towards Poland, firstly in its rule of law opinion under the New Framework and then, after a failed period of dialogue, in the first rule of law recommendation. The Commission highlighted that recent Polish laws raised concerns over the effectiveness of judicial review. Indeed, it stressed 'the fact that the Constitutional Tribunal is prevented from fully ensuring an effective constitutional review adversely affects its integrity, stability and proper functioning, which is one of the essential safeguards of the rule of law in Poland' and acknowledged that the reforms adopted by Poland constituted a 'systemic threat to the rule of law'. ${ }^{\text {XxII }}$ It then invited the Polish authorities to take measures to urgently address this threat.

The deadline set by the recommendation expired on 27 October 2016. On that day, in its reply, the Polish government opposed all the issues raised by the Commission and no initiative was announced to accommodate its concerns (Kroet 2016). In the meantime, new 
measures taken by Warsaw raised further concerns in Brussel and drew the attention of other European Institutions. xxxIII

These developments were taken into account in the subsequent rule of law recommendation, issued by the Commission on 21 December 2016, where it recalled that the situation in Poland continued to pose a systemic threat to the rule of law and invited Warsaw to address the issues already raised in the previous recommendation and take action within two months. ${ }^{\text {Xxiv }}$ Moreover, a new source of concern was the 'Law on the status of judges' which allowed only those judges who took the oath before the President of the Republic to receive cases by the President of the Tribunal. This seemed a precise attempt to target the three judges unlawfully nominated in December 2015, who had already been sworn in by the President of the Republic (Koncewicz 2016b). In addition, the Commission expressed its concerns with respect to the procedure to appoint a new President of the Tribunal, whose term of office ended on 19 December 2016. The two major measures on the basis of which a new President of the Tribunal was elected were the 'Law on organisation and the procedure before the Constitutional Tribunal' and the 'Law on introducing the Law on the status of the judges and on the organisation and procedure before the Tribunal' ('Implementing Law'). The combination of these acts resulted in the General Assembly of the Tribunal being composed by those judges who took the oath before the President of the Republic. It is worth remembering that according to the Polish constitution the candidates to these offices are appointed on the basis of a list proposed by the General Assembly. Therefore, the judges unlawfully elected in December 2015 could participate in the election process, while those elected by the previous Parliament in October 2015 could not. ${ }^{\text {Xxv }}$ On 21 December Julia Przyłęsksa was appointed as new President of the Tribunal by the President of the Republic. Since the notice for the convocation of the General Assembly was very short and the possibility to postpone it was denied, only six judges took part in the election. According to the Commission, the procedure that led to her election was 'fundamentally flawed as regards the rule of law' ${ }^{\text {XxvI }}$ Thus, it invited Poland to guarantee a constitutional review of the Tribunal as regards the three new and contested laws. ${ }^{\text {XxxvII }}$

Once again, the outcome of the dispute was not successful and the pattern repeated itself: Poland continued to disregard both European values and the Commission's 
recommended actions, while the latter could do no better than issuing recommendations and engaging in an ineffective dialogical approach (Pech and Scheppele 2017b). ${ }^{\text {XxxvII }}$

It is also worth mentioning that in the meantime the PiS government has also taken other serious and unprecedented measures: limitations to the independence of the media; contentious electoral reform (Sadurski 2018), substantial and sustained opposition to the EU migrant relocation scheme; a controversial 'memory law' (Gliszczyńska-Grabias and Kozłowski 2018); and the unlawful logging of the Białowieza forest, a UNESCO World Heritage site. ${ }^{\text {Xxxix }}$

In July 2017 the Commission issued the third rule of law recommendation where it disapproved of the fact that none of the actions suggested in its previous recommendations had been carried out. Furthermore, it expressed further concerns as regards four new draft laws which 'contain a number of other sensitive provisions from the point of view of the rule of law and the separation of powers' ${ }^{\mathrm{XL}}$ the Law on the National School of Judiciary; the Law on the Ordinary Courts Organisation; the Law on the National Council for the Judiciary and the Law on the Supreme Court.

The Law on the Ordinary Courts, particularly, drew attention as in the Commission's view it breaches EU law. Therefore, the Commission decided to launch an infringement procedure for dealing with the some of the most problematic issues of this law, namely the different retirement ages of judges on the basis of gender and the discretionary power given to the Minister of Justice as regards the dismissal of judges and the extension of their mandate. ${ }^{\mathrm{XLI}}$

The Law on the National Council for the Judiciary and the Law on the Supreme Court were vetoed by Polish President Duda in July 2017. Unfortunately, two months later Duda presented his own draft versions of the two laws, both very disappointing. Among the principal changes they introduced, the first bill envisaged the interruption of the constitutional term of office of all the current members of the National Council for the Judiciary, an institution specifically envisaged for guaranteeing judicial independence, and the election of their substitutes. The mechanism for judicial members' appointment was not much different from the one proposed in the previous bill since the Polish parliament (Sejm) was entrusted with such a task, although a three-fifths majority was introduced (Matczak 2017). 
With respect to the draft law on the Supreme Court, it envisaged the retirement of high court judges at the age of 65 (the former limit was 70). Since this provision also applied to current sitting judges, it would force the retirement of nearly 40 percent of the court's judges in a short period of time: such a measure not only would undermine the current judges' 'security of tenure' but also endanger 'the independence of the Supreme Court in general'. XLII

The reply of the Polish Government of the Commission's recommendation was sent in August 2017. It came as no surprise that Warsaw disagreed with all the concerns expressed in the recommendation ${ }^{\text {XLIII }}$ and made no mention of any measures to address them. XLIV And besides, on 8 December 2017, the Sejm adopted the two problematic laws, which were then approved by the Senate one week later.

\section{The triggering of Article 7 TEU against Poland: a (late) step in the right direction?}

In light of the difficulties encountered in engaging Poland in a constructive dialogue, on 20 December 2017 the European Commission (finally) decided to submit a reasoned proposal to the Council for a decision on the determination of 'a clear risk of a serious breach by the Republic of Poland of the rule of law referred to in Article 2 TEU'. XLV The Commission found that in two years Poland had adopted 13 laws which heavily altered the structure of the judicial system, allowing political power 'to interfere significantly with the composition, the powers, the administration and the functioning' of judicial authorities and bodies. ${ }^{\text {XVVI }}$ According to the draft Decision, the Council should assess the clear risk of a serious breach by Poland of the rule of law and also recommend that the independence of the Tribunal be restored, its judgments fully implemented and its members lawfully appointed; whilst the four laws challenged in Recommendation 2017/1520 should be 'amended in order to ensure their compliance with the requirements relating to the independence of the judiciary, the separation of powers and legal certainty. XLVII

Additionally, the Commission referred in the infringement proceeding against Poland to the breaching of the principle of equal treatment of men and women before the Court of Justice. ${ }^{\mathrm{XLVIII}}$ At the same time, it also decided to issue a fourth rule of law 
recommendation where the key sources of concerns were the two recently approved acts, the Law on the Supreme Court and the Law on the National Council for the Judiciary, which, in the words of the Commission, 'significantly increase the systemic threat to the rule of law as identified in the previous Recommendations' XLIx The Commission, therefore, suggested specific amendments and actions as regards the two most recent and contested laws, as well as reiterating the proposals recommended in its previous recommendations which so far have not be addressed by Warsaw. ${ }^{\mathrm{L}}$ A three-month deadline to comply with the recommendation was set. ${ }^{\text {LI }}$

The Polish Government actually responded to the Commission's concerns expressed in the fourth rule of law recommendation by the established deadline of the 20 March 2018. It seemed that Warsaw accepted making some minimal changes, but not in the most critical measures targeted by the Commission (Wróbel 2018). ${ }^{\text {LI }}$ Once again, the Polish government demonstrated to have failed to grasp the essence of the Commission's concerns. Rather than pave the way for a real dialogue between the two parts, the Polish answers will risk further delaying the procedure under Article 7(1).

In the light of the inadequate replies of the Polish government, the procedure under Article 7(1) is still ongoing, although it is making very slow progress. On 26 June 2018, the Council (General Affairs configuration) held a first hearing under Article 7(1) and the Member States' Ministers had an exchange with Poland on the major problems identified. At the end of the meeting, the first Commission Vice-President Frans Timmermans restated that 'the systemic threat for the rule of law persisted' and therefore the dialogue shall continue (De La Baume and Herszenhorn 2018b). The next General Affairs Council will assess the Polish responses and also decide on the follow-up steps under the Article 7 procedure.

Considering the severe deterioration of the rule of law situation in Poland over the last two years, one might reasonably wonder what the Commission has waited for before triggering the Article 7(1) procedure. Although the Commission's Rule of Law Framework did not oblige it to trigger Article 7 at the end of the third step, Poland's clear rejections of the Commission's demands made the non-activation of such a provision quite difficult to justify. 
So why did the Commission wait so long before taking such a decision? Probably, one of the reasons relates to the well-known reluctance of both the Council and the European Council to deal with the issue, as shown by the fact that neither of them actively supported the launch of the New Framework against Poland. Another reason may relate to the fact that both Hungary and Poland (the latter learning the lesson of the former) have been deploying a very clever and disingenuous strategy: on the one hand, they have made violations which, in themselves, may not constitute a sufficiently serious basis to speak of systematic breach of the rule of law. On the other hand, they have acted through 'tactical retreats' and adopted 'the most minimalistic formal remedies when found in breach of EU law, leaving values-violating practices in place' (Pech and Scheppele 2017a). ${ }^{\text {LIII }}$

However, while the situation in Poland has already reached an indefensible level, the failure of the main instruments at the Union's disposal has also created the need for a stronger response.

Indeed, the Commission's decision to trigger Article 7(1) represents the last resort solution in the never-ending dispute against Poland. Such a development had become inevitable in order to both send a clear signal that the rule of law 'is a must' in the EU and restore the credibility of European Institutions.

It is worth reiterating that Article 7(1) should not be understood as a mere determination but as 'a sanction by itself' (von Bogdandy 2016). If the Council ultimately makes the determination of 'a clear risk of serious breach' of the rule of law, the Polish government will see its reputation seriously damaged, while it will be hugely difficult for it to ignore such a formal outcome. Moreover, it has been suggested that the initiation of Article 7(1) may act as a catalyst for other developments, such as a more serious evaluation by the Commission of the opportunity of suspending EU funds against Poland or a strong standpoint of the Court of Justice (Kochenov, Pech and Scheppele 2017). Such an interpretation, coupled with the extremely high political thresholds required by the procedure under Article 7(2), as we have discussed, may partially explain why the Commission has decided to trigger the Article 7(1) procedure rather than the one envisaged by the following paragraph; in a situation such as the Polish one the disregard of the rule of law can no longer be regarded as a mere 'threat'. 
While it remains extremely difficult to say how the political scenario will evolve, the Commission's decision to (finally) propose the triggering of Article 7(1) TEU is an important step, being the very first time in the history of the EU. Employing Article 7(1) TEU would be beneficial, firstly, as it would emphasise the role of the rule of law within the Union, reinforcing and reiterating its structure as 'a Community based on the rule of law'. Secondly, it would contribute to the re-establishment of EU credibility when it comes to its founding values, a remarkable step in a period when the Union's authority is regularly challenged, both internally and externally.

Nevertheless, by the time the Commission took the initiative, the response had become not only unavoidable but also quite inadequate. Indeed, it should have acted much earlier, as the deterioration of the principle of judicial independence in Poland was foreseeable at least from autumn 2016. It should have done so to prevent both the backsliding of the rule of law in Poland and to show its teeth after the failed outcomes of its first recommendations adopted under the New Framework. Despite some vagueness of the criteria for triggering Article $7 \mathrm{TEU}$, there is little doubt that the liberticidal process ongoing in Poland since late 2015 amounts to a serious violation of the rule of law as set out in Article 2 TEU. The reluctance of both the EU institutions and the Member States to activate the preventive mechanism in due time can hardly be justified on legal grounds and has a very strong political component.

Furthermore, the Commission still has made little effort to address the situation in Hungary, ${ }^{\text {LIV }}$ a country which started to undertake illiberal measures long before Poland and which nowadays may be described as a 'mafia state' (Magyar 2017). Yet, there is also something paradoxical in not having previously challenged the Hungarian authoritarian measures adopted from 2010. By losing the battle against Hungary, the EU also lost much of its credibility, as well as the first and crucial fight against authoritarian backslidings.

In this respect, the European Parliament seems much more willing to take a stronger stance against rule of law violations. Indeed, the EP not only supported the Commission's Article 7(1) proposal against Poland at the earliest stage, ${ }^{\mathrm{LV}}$ but is also considering the possibility of triggering the same procedure against Hungary. At present, the Committee on Civil Liberties, Justice and Home Affairs (LIBE) has approved a draft proposal asking the Council to trigger the Article 7(1) procedure against Hungary. ${ }^{\text {LVI }}$ Yet, the EP's limited powers as far as Article $7 \mathrm{TEU}$ is concerned very much restrict its scope for action. 
Besides the EP, another major EU institution has started to take a strong stand on the matter: the Court of Justice. The renewed judicial activism of the Court in the Białowiezia Forest case, ${ }^{\mathrm{LVII}}$ in the Associação Sindical dos Juizes Portugueses judgment, ${ }^{\mathrm{LVIII}}$ and, more recently, in the $L M$ judgment, ${ }^{\mathrm{LX}}$ is illustrative in this respect. ${ }^{\mathrm{LX}}$ For what concerns the enforcement of the rule of law in the EU, the CJEU is increasingly demonstrating its willingness to play a role in the picture, despite the limits that Article 7 TEU poses to its competence.

Given that the Member States seem reluctant to show their teeth against rule of law violations, the procedure under Article 7(1) TEU risks being slowed down further; perhaps further analysis should explore the role of these two institutions in the enforcement of European values.

\section{Conclusions}

In light of the analysis and the considerations made above, it is now possible to draw some conclusions as regards the EU's approach towards Poland's rule of law problems and whether the latter case contributed to the transformation of Article 7 TEU in becoming an active instrument for values enforcement.

Although the Commission's New Framework was conceived in complementarity with both the Article 7 TEU procedures and the traditional infringement proceedings, this new mechanism contributed to the further characterisation of Article 7 as a last-resort, nuclear, option. As already recalled, such a connotation does not reflect the nature and the spirit of the procedures envisaged by the provision. There is nothing nuclear in using a mechanism foreseen by the EU Treaties for tackling a specific worrisome situation of value-violation, or the risk thereof. Procedures provided by EU law are indeed there to be applied. It should also be noted that while the voting requirements of Article 7 are particularly high, at least as regards the sanctioning mechanism the thresholds can be reached in an easier way. If deployed at the right time and wisely, the Article 7(1) procedure can help to signal the risk of a serious breach of EU values before it materialises. Rather than being nuclear, it has instead a preventive function (Bonelli 2017).

Alas, the EU institutions have failed to take advantage of this instrument. By delaying the application of Article 7(1) TEU for an unreasonable period of time (in order either to give preference to more dialogical instruments or to address minor issues through 
infringement procedures), EU institutions have simply postponed the moment when that provision will possibly be invoked (Kochenov and Pech 2015: 529). Indeed, as the Polish case is sadly showing, once authoritarian power has been consolidated, the use of the 'barking procedure' becomes much less reasonable and feasible.

This is not to say that Article 7 should be used in a careless and uncritical way. As already acknowledged, the use of this instrument, and especially of the sanctioning mechanism, runs the risk of increasing popular resistance and democratic backlashes against the EU. However, rather than acting as a deterrent from its use, such considerations should instead promote a wise and proper application of Article 7 in cases when it is needed to address or prevent a critical situation of value-violation.

In the Work Programme 2018, the Commission proposed a new initiative to strengthen the enforcement of the rule of law in the European Union' to be launched before the end of 2018. ${ }^{\text {LXI }}$ There is little clue as regards the form that such an initiative might take. ${ }^{\mathrm{LXII}}$ Yet, we can at least say what it should not be: another device to seek avoidance of EU Treaties or a mechanism to further duplicate or, worse, delay current instruments and procedures. The Union may well lose the battle against authoritarian illiberal forces, but at least it has to fight for its values.

Unfortunately, in practice, things seem to be moving in the opposite direction. While in the literature the 'nuclear weapon' myth about Article 7 has largely been dismantled (Kochenov 2017: 8;12), in the realm of politics the Article cannot be considered a suitable instrument. Indeed, both the EU institutions and several Member States still do not appear inclined to use it. The events of the Polish rule of law crisis, and the attempts of the Commission to tackle this, sadly demonstrated it. Therefore, if referring to Article 7 TEU as a 'nuclear option' is undoubtedly a misnomer, its highly political nature and the vague criteria for its activation cast a shadow over its effective implementation.

The Commission's decision to (finally) propose the triggering of Article 7(1) TEU is an important step, being the very first time in the history of the EU and a restatement of its structure as a Community based on the rule of law. Nevertheless, such a step should not be underestimated. In all likelihood, the Member States will do their best to avoid a direct vote against Poland (Bodalska 2018). A decision to simultaneously trigger the Article 7(1) procedure against both Poland and Hungary could represent a possible way out from a 
legal point of view, at least as it could preclude each country from vetoing sanctions against the other in the event of a procedure under Article 7(2). ${ }^{\text {LXIII }}$ Yet, politically speaking, the Commission has so far shown little intention to go in this direction and it seems that there is also internal disagreement as regards the feasibility of going ahead with the Article 7(1) procedure against Poland (De La Baume and Herszenhorn 2018a).

What clearly emerges from the overall analysis is the Union's difficulties in dealing with the 'Copenhagen dilemma', LXIV that is, the gap between the commitment of candidate countries to respect the rule of law at the time of accession to the EU and the Union's actual capacity to enforce these criteria. The EU has to act in this respect. If it fails to do so and to address the current rule of law crisis in an appropriate way, there will be serious consequences for the Union as a whole. Indeed, the rule of law crisis is not just one among the many crises the Union is facing, as the rule of law is a key prerequisite for both the application of EU law throughout the Union and the maintenance of mutual trust among Member States and European citizens (Closa 2016: 15-16). Moreover, the credibility of the Union also depends on its capacity to uphold its shared values and, in particular, the rule of law. In a nutshell, if its founding values are no longer respected and upheld, the very existence of the EU integration project in its entirety risks being severely jeopardised.

\footnotetext{
* Please add your qualification here.

I Venice Commission, Report on the rule of law, 25-26 March 2011, p.10. Such a definition has also been embraced by the European Commission on a number of occasions. See for instance: European Commission, Annexes to the Communication to the European Parliament and the Council, A new EU framework to strengthen the rule of law, Strasbourg, 11 March 2014.

II As the issue of the enforcement of EU values in general, and the rule of law in particular, is constantly evolving, in preparing this paper the effort was made to closely monitor - and give account of - the most recent events and developments ongoing in Poland and at the EU level, as well as the comments and the suggestion advanced by the scholars. In this respect, this work discusses the latest developments unfolded until the end of August 2018.

III Supra, note 1.

IV See: EUR-Lex, Glossary of Summary, under the term 'Accession criteria (Copenhagen criteria)', https://eurlex.europa.eu/summary/glossary/accession criteria copenhague.html, last access 30 June 2018.

$\mathrm{V}$ Nowadays it can be said that the rule of law has not only an internal dimension in the EU legal order: respect for the rule of law shall be promoted outside the European borders by the Union and the Member States (Articles 3(5) and $21 \mathrm{TEU}$ ) and -importantly - its respect and commitment to its promotion is a formal accession requirement for candidate countries (Article 49 TEU). For a critical analysis of the external dimension of the EU rule of law see Pech, 2015.

VI Treaty of Amsterdam amending the Treaty on European Union, the Treaties establishing the European Com

munities and certain related acts, 97/c 340/01, Article F.1.

VII Statement by the Portuguese Presidency of the EU on behalf of XIV Member States, 31 January 2000, https://www.cvce.eu/obj/statement by the portuguese presidency of the eu on behalf of 14 member
} 
states 31 january 2000-en-8a5857af-cf29-4f2d-93c9-8bfdd90e40c1.html.

VIII European Parliament resolution on the result of the legislative elections in Austria and the proposal to form a coalition government between the ÖVP (Austrian People's Party) and the FPÖ (Austrian Freedom Party), Brussels, 3 February 2000, $\quad$ http://www.europarl.europa.eu/sides/getDoc.do?pubRef=-//EP//TEXT+TA+P5-TA-2000$0045+0+\mathrm{DOC}+\mathrm{XML}+\mathrm{V} 0 / / \mathrm{EN}$.

IX On this issue see also: Lachmayer (2017).

$\mathrm{x}$ The group, formed by the former Finnish president Martti Ahtisaari, the former Spanish foreign minister Marcelino Oreja and the German international lawyer, Jochen Frowein, issued the report on 8 September 2000. The document stated that the Austrian Government was committed to European values and, although the FPÖ program and many statements of its members were not in line with EU values and standards, FPÖ ministers had worked according to the Government's commitment (Ahtisaari, Frowein and Oreja 2001, par. 108-113).

XI Treaty of Nice Amending the Treaty on European Union, the Treaties establishing the European Communities and certain related acts (2001/c 80/01), Article 1(1).

XII Communication from the Commission to the Council and the European Parliament on Article 7 of the Treaty on European Union - Respect for and promotion of the values on which the Union is based, COM/2003/0606 final, Brussels, 15 October 2003, p. 5.

XIII In recent years, several cases were debated as the possible violation of EU values. The most visible case of rule of law backsliding is Hungary, where since 2010 the Viktor Orbán's government has adopted a significant number of illiberal measures and actions predicated on a very particular idea of preserving the country's sovereignty and constitutional identity. For further analysis on the Hungarian case: Magyar 2016.

XIV "We need a better developed set of instruments- not just the alternative between the "soft power" of political persuasion and the "nuclear option" of article 7 of the Treaty' (Barroso 2012).

$\mathrm{XV}$ It has been argued in the literature that Article $7 \mathrm{TEU}$ also entrusts the Commission with the monitoring competence to determine the existence of a serious breach by a Member State of the Article 2 TEU values, as well as the risk thereof (Mori 2016: 6).

XVI What it is known for sure is that EU membership cannot be suspended, since only Article 50 TEU paves the way for leaving the Union on the basis of a voluntary withdrawal of the concerned Member State (Besselink 2017: 131).

XVII 'The Union shall respect the equality of Member States before the Treaties as well as their national identities, inherent in their fundamental structures, political and constitutional, inclusive of regional and local self-government. It shall respect their essential State functions, including ensuring the territorial integrity of the State, maintaining law and order and safeguarding national security. In particular, national security remains the sole responsibility of each Member State'.

xVIII CJEU, Case 26-62, van Gend \& Loos, [1963], ECLI:EU:C:1963:1; CJEU, Case 6-64, Flaminio Costa v E.N.E.L, [1964], ECLI:EU:C:1964:66.

XIX CJEU, Opinion 2/13, [2014], ECLI:EU:C:2014:2454, par.167.

$\mathrm{xx}$ 'This legal structure is based on the fundamental premise that each Member State shares with all the other Member States and recognises that they share with it, a set of common values on which the EU is founded, as stated in Article 2 TEU. That premise implies and justifies the existence of mutual trust between the Member States that those values will be recognised and, therefore, that the law of the EU that implements them will be respected'. Ibid, par. 168 .

$\mathrm{XXI}$ It is worth mentioning that, according to the 'wise men' report (supra, note 10), the rise of nationalist feelings in Austria was a side effect of the measures taken by fourteen Member States against the Haider government, since they were sometimes 'wrongly understood as sanctions directed against Austrian citizens' (Ahtisaari, Frowein, Oreja, 2001: par. 116)

XXII See Communication from the Commission to the Council and the European Parliament on Article 7 of the Treaty on European Union, cit. and European Parliament legislative resolution on the Commission communication on Article 7 of the Treaty on European Union: Respect for and promotion of the values on which the Union is based (COM(2003) $606-C 5$ 0594/2003 - 2003/2249(INI)), Brussels, 20 April 2004.

XXIII As defined by the CJEU in Case 294/83, Partie Ecologiste "Les Verts" v. Parliament, [1986] EU:C:1986:166, par. 23.

XXIV Communication from the Commission to the European Parliament and the Council - A new EU Framework to strengthen the Rule of Law COM/2014/0158 final Brussels, 19 March 2014.

xxv Commission Recommendation (EU) 2016/1374 of 27 July 2016 regarding the rule of law in Poland, par. 6-10. 
XXVI Ibid par. 28.

XXvII Venice Commission, Opinion on Amendments to the Act of 25 June 2015 on the Constitutional Tribunal of Poland, No 833/2015, 11 March 2016, par. 88.

XXVIII Article 38(4)(5), The Constitutional Tribunal act of 22 July 2016. Published by The Venice Commission, Opinion No. 860/2016, Strasbourg, 7 September 2016.

xxIx Venice Commission, Opinion on the Act on the Constitutional Tribunal of Poland, No 860/2016, 14 October 2016, par. 43-48.

xxx Ibid par. 37-39.

xxxi See for a comment: Starski 2016.

xxxiI Recommendation 2016/1374, par.72.

xxxiII See the European Parliament resolution of 14 September 2016 on the recent developments in Poland and their impact on fundamental rights as laid down in the Charter of Fundamental Rights of the European Union (2016/2774(RSP)), http://www.europarl.europa.eu/sides/getDoc.do?pubRef=-//EP//TEXT+TA+P8-TA-20160344+0+DOC+XML+V0//EN

XxxIV Commission Recommendation (EU) 2017/146 of 21 December 2016 regarding the rule of law in Poland complementary to Recommendation (EU) 2016/1374, par. 68.

xxxv Recommendation 2017/146, par. 43-46.

xxxvi Ibid par. 58-59.

xxxvII Ibid par. 66.

XXXVIII For what concerns the political belief behind the Polish reforms, the rhetoric applied by the ruling party has been almost the same: a continuous discredit of the polish post-1989 institutions and laws, perceived as an attempt to restore the communist past. Indeed, according to the discourse of Mr. J. Kaczyński, the PiS leader, the previous communist elite still enjoys great power in the country after having colluded with the liberal politicians (Foy, 2016).

xxxix In November 2017 the Court of Justice issued a remarkable decision where it ordered to Poland to cease all logging operations in the Białowieza forest, except when such activity was essential to ensure the public safety of persons. Surprisingly, it also affirmed its jurisdiction to impose penalty payments in the context of an interim relief ruling under Article 279 TFEU ( $€ 100000$ per day of non-compliance, starting from the date on notification of the order), an absolute novelty for the Court's jurisprudence. Such an outstanding decision clearly stressed the serious threshold that the Polish rule of law crisis has reached, while restating the fundamental role that EU values play in the European legal order. CJEU, Order in Case C-441/17 R, European Commission, v. Republic of Poland, [2017].

XL Commission Recommendation (EU) 2017/1520 of 26 July 2017 regarding the rule of law in Poland complementary to Recommendations (EU) 2016/1374 and (EU) 2017/146, par. 44.

XLI According to the Commission, Polish law is contrary to Article 157 TFEU and also breaches the Directive on gender equality in employment (Directive 2006/54). As regards the extension of the powers of the Minister of justice, the Commission stated that such a reform would undermine the independence of the courts, breaching Article 19(1) TFEU read in connection with Article 47 of the EU CFR.

In replying to the letter of formal notice, the Polish authorities denied the existence of any breach of EU law. At present, the Commission has referred the Polish Government to the European Court of Justice as regards the retirement regime introduced by the Law on the Ordinary Courts. European Commission, Press release: Rule of Law: European Commission acts to defend judicial independence in Poland, Brussels, 20 December 2017.

XLII Venice Commission, Opinion on the draft act amending the act on the National Council of the Judiciary, on the draft act amending the act on the Supreme Court, proposed by the President of Poland, and on the act on the organisation of Ordinary Courts, No. 904/2017, 11 December 2017, http://www.venice.coe.int/webforms/documents/default.aspx?pdffile=CDL-AD(2017)031-e.

XLIII Commission Recommendation (EU) 2018/103 of 20 December 2017 regarding the rule of law in Poland complementary to Recommendations (EU) 2016/1374, (EU) 2017/146 and (EU) 2017/1520, Brussels, 20 December 2017, par. (13).

XLIV In a speech on the rule of law in Poland at the EP's LIBE Committee the Vice-President Timmermans stressed that Polish authorities did not announce any concrete measures to address the issues raised in the third rule of law Recommendation, while none of the four letters sent by the Commission to the Polish government inviting them to meet was accepted (Timmermans 2017).

XLV European Commission, Proposal for a Council decision on the determination of a clear risk of a serious breach by the Republic of Poland of the rule of law, Explanatory Memorandum, COM(2017) 835 final, 20 December 2017, par. 172. 


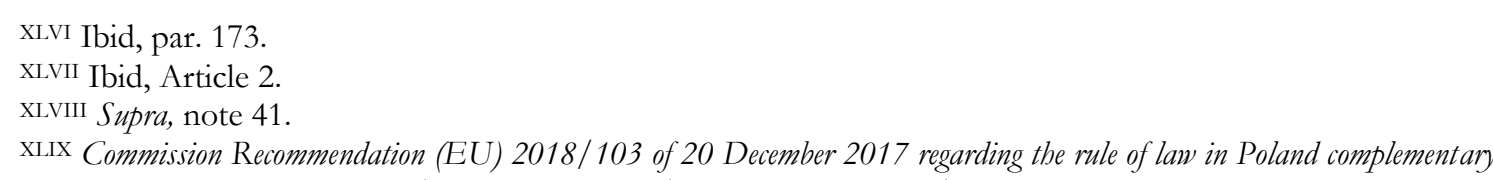
to Recommendations (EU) 2016/1374, (EU) 2017/146 and (EU) 2017/1520, Brussels, 20 December 2017, par. 38.

L Ibid par. 45-49.

LI Ibid par. 50.

LII As a consequence, in July 2018, the Commission launched a new infringement procedure against Poland regarding the Law on the Supreme Court for failure to fulfil the obligations under Article 19(1) TEU and Article 47 of the EU CFR. European Commission - Press release, Rule of Law: Commission launches infringement procedure to protect the independence of the Polish Supreme Court, Brussels, 2 July 2018.

LIII This was the case of the outcome of the infringement procedure against Hungary for having fired its data protection commissioner. In response to the recommendations of the Court of Justice (CJEU, Case C-288/12, European Commission v Hungary, ECLI:EU:C:2014:237), Hungary limited itself to paying compensation to the fired commissioner since it could not reiterate its mistake by firing the new 'independent' one. See also for a comment: Scheppele 2014.

LIV The Commission launched a couple of infringement procedures concerning violations of the rule of law against Hungary; the latest one being the one challenging the Hungarian Higher Education Law, the 'lex CEU' (on 7 December 2017 the case was referred to the Court of Justice). However, so far all have fallen short of addressing the general rule of law problems and had only a limited focus on few technical problems. Beside the already mentioned case regarding the substitution of the Hungarian Parliamentary Commissioner for Data Protection (supra, note 53), the case concerning the 2011 reform that lowered the retirement age of judges from 70 to 62 , leading to the abrupt retirement of more than 200 judges, is illustrative in this respect. The Commission claimed the violation of the principle of non-discrimination on grounds of age, relying on Directive 2000/78/EC on the equal treatment in employment and the Court of Justice found the breach of that principle as stated in Articles 2 and 6(1) of Directive 2000/78 (Case C-286/12). Yet, the thin legal grounds of the Commission's decision are quite disappointing, since it could have relied on much more problematic provisions contained in the law in question, such as the broader issue of the independence of the judiciary.

LV European Parliament, Resolution of 1 March 2018 on the Commission's decision to activate Article 7(1) TEU as regards the situation in Poland, Doc. 2018/2541(RSP).

LVI The proposal will be put to a vote by the EP plenary in mid-September 2018. European Parliament, Press Release, Rule of law in Hungary: Parliament should ask Council to act, say committee MEPs, 25 June 2018, http://www.europarl.europa.eu/news/en/press-room/20180625IPR06503/rule-of-law-in-hungary-

parliament-should-ask-council-to-act-say-committee-meps.

LVII Supra, note 39.

LVIII CJEU, C-64/16, Associação Sindical dos Juižes Portugueses, [2018], EU:C:2018:117.

LIX In the LM case the Court of Justice affirmed that the judicial authority executing a European Arrest Warrant (EAW) could refuse to do so by way of exception when it has proof that the person in respect of whom the EAW was issued will, if surrendered to the issuing judicial authority, suffer a breach of his fundamental right to an independent tribunal and, therefore, of the essence of his fundamental right to a fair trial a right guaranteed by the second paragraph of Article 47 of the Charter' (par. 59). In order to make such an assessment, the executing judicial authority has to collect material 'that is objective, reliable, specific and properly updated' and it also must 'assess specifically and precisely whether, in the particular circumstances of the case, there are substantial grounds for believing that, following his surrender to the issuing Member State, the requested person will run that risk' (par. 61 and 68). Quite importantly, the CJEU specified, as regards the first step of the assessment, that 'information in a reasoned proposal recently addressed by the Commission to the Council on the basis of Article 7(1) TEU is particularly relevant for the purposes of that assessment' (par. 61). Yet, at the same time the Court stated that the executing judicial authority could automatically refuse to execute an EAW 'without having to carry out any specific assessment' only if the European Council had adopted on the basis of Article 7(2) TEU, stating the existence of a serious and persistent breach of the values at Article $2 \mathrm{TE}$ in the issuing Member State (par. 72). CJEU, C-216/18 PPU, Minister for Justice and Equality v LM, [2018], ECLI:EU:C:2018:586.

LX See for further analysis: Lazzerini, 2018: paragraphs 4, 5 and 6. 
LXI Communication from the Commission to the European Parliament, the Council, the European Economic and Social Committee and the Committee of the Regions, Commission Work Programme 2018 An agenda for a more united, stronger and more democratic Europe, COM/2017/0650 final, 24 October 2017, pp. 12-13.

LXII In May 2018 the Commission issued a proposal for a Regulation for suspending EU funds in countries where there are generalised breaches of EU values. European Commission, Proposal for a Regulation of the European Parliament and of the Council on the protection of the Union's budget in case of generalised deficiencies as regards the rule of law in the Member States, Brussels, 2.5.2018 COM(2018) 324 final.

LXIII This position was largely sustained by K.L. Scheppele (2016).

LXIV 'Today everybody mentions the situation in Hungary and Romania. Are we sure that we will not see such a situation again in a couple of weeks in another EU country? Now let us be honest - and some of the parliamentarians have said it very clearly - we face a Copenhagen dilemma. We are very strict on the Copenhagen criteria, notably on the rule of law in the accession process of a new Member State but, once this Member State has joined the European Union, we appear not to have any instrument to see whether the rule of law and the independence of the judiciary still command respect'. European Parliament, Plenary debate on the political situation in Romania, statement by V. Reding, former European Commissioner for Justice, Fundamental Rights and Citizenship, 12 September 2012.

\section{References}

- Ahtisaari Martti, Frowein Jochen and Oreja Marcelino, 2001, 'Report on the Austrian government's commitment to the common European values, in particular concerning the rights of minorities, refugees and immigrants, and the evolution of the political nature of the FPÖ (the wise men report)', International Legal Materials, XL(1): 102-123.

- $\quad$ Barroso José Manuel, 2012, State of the Union address, Speech 12/256, Strasbourg, 12 September 2012, http://europa.eu/rapid/press-release SPEECH-12-596 en.htm.

- Besselink Leonard, 2017, The Bite, the Bark and the Howl: Article 7 and the Rule of Law Initiatives, in in Jakab András and Kochenov Dimitry (eds), The Enforcement of EU Law against the Member States: Methods against Defiance, OUP, Oxford, 128-144.

- $\quad$ Bieber Roland and Maiani Francesca, 2014, 'Enhancing centralized enforcement of EU law: Pandora's toolbox?’, Common Market Law Review, LI(4): 1057-1092.

- Black Ian and Connolly Kate, 2000, 'EU leaders urged to keep Haider out', The Guardian, 29 January 2000, https://www.theguardian.com/world/2000/jan/29/ianblack.kateconnolly.

- Bodalska Barbara, 2018, 'Baltic states against EU sanctions on Poland', Euractiv, 13 March 2018, https://www.euractiv.com/section/justice-home-affairs/news/baltic-states-against-eu-sanctions-on-poland/.

- Bonelli Matteo, 2017, 'Not little, not late: notes on the Commission's activation of Article 7 against Poland', [blog] Law Blogs Maastricht, 28 December 2017, https://www.maastrichtuniversity.nl/blog/2017/12/not-little-not-late-notes-commission's-activation-article7-against-poland.

- $\quad$ Bugaric Bojan, 2016, 'Protecting democracy inside the EU: on article 7 TEU and the Hungarian turn to authoritarianism', in Closa Carlos and Kochenov Dimitry (eds), Reinforcing Rule of Law Oversight in the European Union, OUP, Oxford, 82-102.

- De Búrca Gráinne, 2004, 'Beyond the Charter: How Enlargement Has Enlarged the Human Rights Policy of the European Union', Fordham International Law Journal, XXVII: 679-714.

- Closa Carlos, 2016, 'Reinforcing EU Monitoring of the Rule of Law: Normative Arguments, Institutional Proposals, and Procedural Limitations', in Closa Carlos and Kochenov Dimitry (eds), Reinforcing Rule of Law Oversight in the European Union, OUP, Oxford, 15-35.

- De La Baume Maïa and Herszenhorn David M., 2018a, 'Juncker and Selmayr fight Timmermans on behalf of Poland', Politico, 6 June 2018, https://www.politico.eu/article/jean-claude-juncker-martin-selmayrfight-frans-timmermans-on-behalf-of-poland/.

- De La Baume Maïa and Herszenhorn David M., 2018b, 'EU unpersuaded by Poland's defense at ruleof-law hearing', Politico, 27 June 2018, https://www.politico.eu/article/eu-unpersuaded-by-polands-defenseat-rule-of-law-hearing/. 
- $\quad$ 'Enforcing the rule of law in the EU, In the name of whom?', 2016, Editorial Comments, European Papers, I(3): 771-776.

- Foy Henry, 2016, 'Jaroslaw Kaczynski: Poland's kingmaker', Financial Times, 26 February 2016, https://www.ft.com/content/8238e15a-db46-11e5-a72f-1e7744c66818.

- Gliszczyńska-Grabias Aleksandra and Kozłowski Wojciech, 2018, 'Calling Murders by Their Names as Criminal Offence - a Risk of Statutory Negationism in Poland', [blog] VerfBlog, 1 February 2018, https://verfassungsblog.de/calling-murders-by-their-names-as-criminal-offence-a-risk-of-statutorynegationism-in-poland/.

- Guastaferro Barbara, 2012, Beyond the Exceptionalism of Constitutional Conflicts: The Ordinary Functions of the Identity Clause, Jean Monnet Working Paper No 1.

- Halmai Gábor, 2017, 'The Hungarian National(ist) Constitutional Identity', Quaderni costituquionali, XXXVII(1): 151-154.

- $\quad$ Kochenov Dimitry, 2017, Busting the myths nuclear: A commentary on article 7 TEU, EUI Working Papers, No. 10.

- Kochenov Dimitry and Pech Laurent, 2015, 'Monitoring and Enforcement of the Rule of Law in the EU: Rhetoric and Reality', European Constitutional Law Review, XI(3): 512-540.

- Kochenov Dimitry, Pech Laurent and Scheppele Kim Lane, 2017, ‘The European Commission’s Activation of Article 7: Better Late than Never?', [blog] VerfBlog, 23 December 2017, http://verfassungsblog.de/the-european-commissions-activation-of-article-7-better-late-than-never/.

- Koncewicz Tomasz Tadeusz, 2016a, 'Polish Constitutional Tribunal goes down with dignity', [blog] VerfBlog, 25 August 2016, https://verfassungsblog.de/polish-constitutional-tribunal-goes-down-with-dignity.

- Koncewicz Tomasz Tadeusz, 2016b, 'Constitutional Capture in Poland 2016 and Beyond: What is Next?', [blog] VerfBlog, 19 December 2016, https://verfassungsblog.de/constitutional-capture-in-poland2016-and-beyond-what-is-next/.

- Kroet Cynthia, 2016, 'Polish leader: Commission criticism "amuses me", Politico, 28 July 2016, https://www.politico.eu/article/polish-leader-commission-criticism-amuses-me-jaroslaw-kaczynski-beyongeu-treaty-power/.

- Lachmayer Konrad, 2017, 'Questioning the Basic Values - Austria and Jörg Haider', in Jakab András and Kochenov Dimitry (eds), The enforcement of EU law and values: ensuring member states' compliance, OUP, Oxford, 436-445.

- Lazzerini Nicole, 2018, 'Le recenti iniziative delle istituzioni europee nel contesto della crisi dello Stato di diritto in Polonia: prove di potenziamento degli "anticorpi" dei Trattati?', Osservatorio Sulle Fonti, no. 1/2018: 1-21.

- Magyar Balint, 2016, Post-Communist Mafia State: The Case of Hungary, CEU Press, Budapest.

- Magyar Balint, 2017, 'The EU's Mafia State', Project Syndicate, 21 June 2017, https://www.projectsyndicate.org/commentary/orban-hungary-mafia-state-by-balint-magyar-2017-

06? barrier=accessreg\#comments.

- Matczak Marcin, 2017, 'President Duda is Destroying the Rule of Law instead of Fixing it', [blog] VerfBlog, 29 September 2017, https://verfassungsblog.de/president-duda-is-destroying-the-rule-of-lawinstead-of-fixing-it/.

- Mori Paola, 2016, 'Il rispetto dello Stato di diritto: "affari interni" o questione europea? I nuovi meccanismi di controllo dell'Unione alla prova della Polonia', federalismi.it, no. 25/2016, www.federalismi.it.

- Müller Jan-Werner, 2011, 'Should Brussels resist Hungary's "Putinization”? Or do EU member states have a "democratic over-ride"?', openDemocracy, 30 December 2011, https://www.opendemocracy.net/janwerner-mueller/should-brussels-resist-hungarys-'putinization'-or-do-eu-member-states-have-'democ.

- Pech Laurent, 2015, 'The EU as a global rule of promoter: the consistency and effectiveness challenges', Asia Europe Journal, XIV(1): 7-24.

- Pech Laurent, 2016, 'Commission Opinion of 1 June 2016 regarding the Rule of Law in Poland', [blog] EU Law Analysis, 19 August 2016, http://eulawanalysis.blogspot.be/2016/08/commission-opinion-of1-june-2016.html.

- Pech Laurent and Scheppele Kim Lane, 2017a, 'Poland and the European Commission, Part II: Hearing the Siren Song of the Rule of Law', [blog] VerfBlog, 6 January 2017, 
http://verfassungsblog.de/poland-and-the-european-commission-part-ii-hearing-the-siren-song-of-the-ruleof-law /.

- $\quad$ Pech Laurent and Scheppele Kim Lane, 2017b, Poland and the European Commission, Part III: Requiem for the Rule of Law', [blog] VerfBlog, 3 March 2017, http://verfassungsblog.de/poland-and-theeuropean-commission-part-iii-requiem-for-the-rule-of-law/.

- Pinelli Cesare, 2012, Protecting the Fundamentals: Article 7 of the Treaty on the European Union and Beyond, Foundation for European Progressive Studies, No. 7.

- $\quad$ Sadurski Wojciech, 2010, Adding a Bite to a Bark? A story of Article 7, the EU Enlargement, and Jörg Haider, Legal Studies Research Paper, No 10/01, Sydney Law School.

- $\quad$ Sadurski Wojciech, 2018, 'Who will Count the Votes in Poland?', [blog] VerfBlog, 26 February 2018, https://verfassungsblog.de/who-will-count-the-votes-in-poland/.

- Scheppele Kim Lane, 2014, 'Making Infringement Procedures More Effective: A Comment on Commission v. Hungary, Case C-288/12', [blog] Eutopialaw, 29 April 2014, https://eutopialaw.com/2014/04/29/making-infringement-procedures-more-effective-a-comment-oncommission-v-hungary-case-c-28812-8-april-2014-grand-chamber/.

- Scheppele Kim Lane, 2016, 'Can Poland be Sanctioned by the EU? Not Unless Hungary is Sanctioned Too', [blog] VerfBlog, 24 October 2016, https://verfassungsblog.de/can-poland-be-sanctioned-by-the-eu-notunless-hungary-is-sanctioned-too/.

- $\quad$ Starski Paulina, 2016, 'The Power of the Rule of Law: The Polish Constitutional Tribunal's Forceful Reaction', VerfBlog, 17 March 2016, https://verfassungsblog.de/the-power-of-the-rule-of-law-the-polishconstitutional-tribunals-forceful-reaction/.

- The Rule of Law in the Union, the Rule of Union Law and the Rule of Law by the Union: Three interrelated problems', 2016, Editorial Comments, Common Market Law Review, LIII(3): 597-605.

- Timmermans Frans, 2017, Opening remarks on the Rule of Law in Poland, at the European Parliament's Committee on Civil Liberties, Justice and Home Affairs, Brussels, 7 November 2017.

- von Bogdandy Armin, 2016, 'How to protect European Values in the Polish Constitutional Crisis', [blog] VerfBlog, 31 March 2016, http://verfassungsblog.de/how-to-protect-european-values-in-the-polishconstitutional-crisis/.

- von Bogdandy Armin et al., 2012, 'A Rescue Package for EU Fundamental Rights - Illustrated with Reference to the Example of Media Freedom', [blog] VerfBlog, 15 February 2012, https://verfassungsblog.de/a-rescue-package-for-eu-fundamental-rights-illustrated-with-reference-to-theexample-of-media-freedom/.

- von Bogdandy Armin and Ioannidis Michael, 2014, 'Systemic Deficiency in the Rule of Law: What It Is, What Has Been Done, What Can Be Done', Common Market Law Review, LI(1): 59-96.

- $\quad$ von Bogdandy Armin and Schill Stephan, 2011, 'Overcoming absolute primacy: respect for national identity under the Lisbon Treaty', Common Market Law Review, XLVIII(5): 1417-1453.

- Wróbel Aleksandra, 2018, 'Poland retreats on controversial laws', Politico, 22 March 2018, https://www.politico.eu/article/poland-law-and-justice-retreats-on-controversial-laws/. 